\title{
Pengembangan Model Make A Match Untuk Membangun Karakter Di Sekolah Dasar
}

\author{
Baiq Sarlita Kartiani dan Eneng Garnika \\ Dosen FIP IKIP Mataram \\ s.kartiani04@gmail.com
}

Tujuan dari penelitian ini untuk mengetahui kelayakan dan keefektifan model make a match pada proses pembelajaran untuk membangun karakter siswa sekolah dasar. Penelitian ini dilaksanakan di SD Negeri 1 Dasan Baru kecamatan Kediri kabupaten Lombok Barat. Jenis penelitian yang digunakan yaitu penelitian dan pengembangan yang terdiri dari 10 tahap. Adapun tahapannya yaitu (1) Potensi dan Masalah, (2) Pengumpulan Data, (3) Desain Produk, (4) Validasi Desain, (5) Revisi Desain, (6) Ujicoba Produk, (7) Revisi Desain, (8) Ujicoba Pemakaian, (9) Revisi Produk, (10) Produk Akhir. Instrument yang digunakan dalam penelitian ini adalah angket, lembar evaluasi, dan pedoman wawancara. Sedangkan ujicoba dilakukan dengan tiga tahapan yaitu ujicoba terbatas, ujicoba lapangan, dan ujicoba produk operasional. Adapun untuk validator ahli digunakan 4 ahli yaitu ahli pembelajaran, ahli materi, dan ahli media. Hasil yang diperoleh dari masing validator (ahli) sebagai berikut: ahli materi diperoleh skor sebesar $94 \%$ (layak diujicoba), ahli media diperoleh skor sebesar 84\%, dan ahli pembelajaran diperoleh skor sebesar 93.28\%. sedangkan pada tahap ujicoba terbatas dan ujicoba lapangan diperoleh skor rerata yaitu 95.5 dan 91.20 dikategorikan sangat baik. Sedangkan rerata hasil karakter setelah digunakan model make a match dengan skor 0,4 dikategorikan tinggi dan pada analisis data siswa yang menggunakan model make a match nilai karakter siswa sebesar 90 di kategorikan sangat baik.

\section{Kata Kunci: Pengembangan, Model Make a Match, Karakter.}

\section{Pendahuluan}

Pendidikan untuk membangun karakter mulai banyak dibahas dan seolaholah menjadi baru ketika negeri ini mulai dilanda berbagai krisis, termasuk krisis moral dengan bukti berbagai media memberitakan kehidupan sosial yang semakin carut marut. Permasalahan hukum, ekonomi, pendidikan, dan lainnya masih menjadi pemandangan yang menghiasi pemberitaan media masa baik cetak maupun elektronik. Dalam bidang hukum, berita yang menyajikan tentang para pejabat korupsi mulai dari daerah sampai pusat gencar ditayangkan. Kasus ini sebagai bukti masih rendahnya kesetiaan, kepedulian dan penghargaan para penguasa terhadap negeri tercinta ini. Menurut Enah (2011 : 175) pendidikan jelas secara konseptual telah dinyatakan dalam perundang-undangan bahwa pendidikan sebagai upaya untuk mewujudkan insan yang spiritual keagamaan, matang dalam pengendalian diri, kepribadian, kecerdasan, akhlak mulia serta memiliki keterampilan yang diperlukan dirinya, masyarakat, bangsa dan negara. Dasar yang mulia tersebut ternyata belum mengakar ke dalam implementasinya sehingga krisis karakter muncul dalam berbagai bentuk.

Tujuan pendidikan yang mulia pada implementasinya belum semua pendidik mampu mengimlpementasikannya dengan baik, sebagai contoh yang terjadi di Nusa Tengggara Barat khususnya di SD Negeri 1 Dasan Baru Kecamatan Kediri Lombok Barat, masih banyak siswa yang tidak percaya diri, belum bertanggungjawab, dan belum mau bekerjasama.

Model Make a Match (Mencari Pasangan) adalah salah satu model alternatif yang dapat diterapkan kepada siswa. Penerapan model ini dimulai dari teknik, yaitu siswa disuruh mencari pasangan kartu yang merupakan jawaban/soal sebelum batas waktunya. Dengan menerapkan model cooperatif make a match kegiatan pembelajaran yang dilakukan akan lebih menyenangkan dan juga lebih antusias untuk pengembangan karakter positif siswa, siswa juga akan terlihat lebih aktif, suasana pembelajaran juga lebih menyenangkan karena model cooperatif make a match, sehingga siswa tidak merasa terbebani dalam pembelajaran konvensional. 
Adapun masalah yang diambil adalah : (1). Bagaimana karakteristik model make a match yang dapat digunakan untuk membangun karakter siswa Sekolah Dasar? (2). Bagaimana keefektifan model make a match dalam membangun karakter siswa Sekolah Dasar. Tujuan penelitian ini adalah (1). Untuk mengetahui karakteristik model make a match yang dapat digunakan untuk membangun karakter siswa Sekolah Dasar. (2). Untuk mengetahui keefektifan model make a match dalam membangun karakter siswa Sekolah Dasar.

\section{METODE PENELITIAN}

\section{Jenis Penelitian}

Jenis penelitian ini adalah research and development (penelitian dan pengembangan). Penelitian ini mengembangkan model make a match (mencari pasangan untuk membangun karakter peserta didik.

Tahapan-Tahapan

Pengembangan

Penelitian

Metode penelitian ini mengunakan pendekatan penelitian dan pengembangan (Research and Development). Tahapan pengembagan penelitian ini terdiri dari10 langkah seperti yang dikemukakan oleh Borg and Gall (1983:775). Terdapat yaitu: (1) Research and Information Collecting (mengumpulkan informasi dan melakukan penelitian awal); (2) Planning ( perencanaan); (3) Develop Preliminary of Product ( mengembangkan produk awal); (4) Preliminary Field Testing (uji coba awal); (5) Main Product Revision ( melakukan revisi untuk menyusun produk utama); (6) Main Field Test (melakukan uji coba lapangan); (7) Operational Product Revision (melakukan uji coba untuk menyusun produk operasional); (8) Operational Field Testing (melakukan uji coba penyempurnaan; (9) Final Product Revision (melakukan revisi produk akhir); dan (10) Dissemination and implementation (penyebaran dan pelaksanaan).

\section{Rancangan Penelitian}

Langkah prosedur pengembangan produk yang dikemukakan oleh Borg and Gall sebagai berikut :

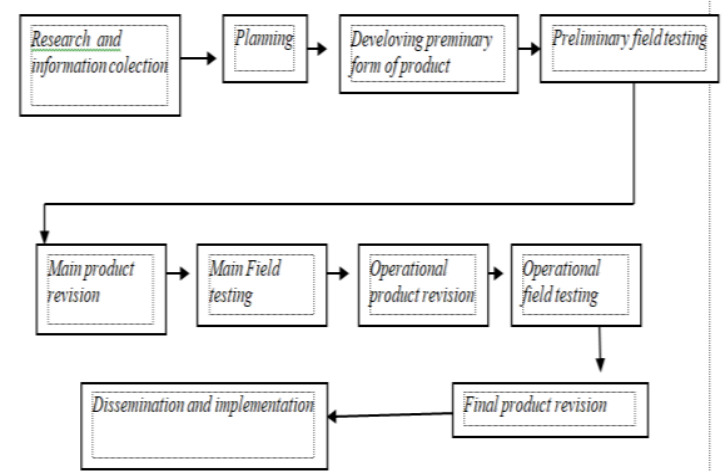

Gambar 1. Rancangan Penelitian Pengembangan Model Borg and Gall (1983: 775)

Berikut ini akan dijelaskan tahapan-tahapan dalam pengembangan model make a match untuk membnagun

1. Penelitian dan pengumpulan Data Awal

Tahap ini merupakan tahap awal atau persiapan untuk pengembangan. Peneliti melakukan kajian terhadap konsep-konsep yang berkenaan dengan model make a match dan perangkat pembelajaran yang akan digunakan. Kajian yang dilakukan meliputi kajian terhadap draf perangkat pembelajaran untuk siswa SD. Selanjutnya melakukan tahapan analisis kebutuhan yang bertujuan mengetahui kebutuhan guru dan siswa pada saat proses pembelajaran. Menganalisis perangkat pembelajaran yang digunakan guru dalam pembelajaran, peneliti menggunakan wawancara dan observasi.

2. Perencanaan

Pada tahap perencanaan (planning) meliputi kegiatan dan menetapkan perangkat pembelajaran dengan model make a match untuk membangun karakter siswa SD yaitu RPP.

3. Pengembangan Produk Awal.

Tahap-tahap kegiatan yang dilakukan dalam mengembangkan produk awal diantaranya mengembangkan model make match untuk membangun karakter siswa SD Negeri 1 Dasan Baru. Perangakat pembelajaran yang dikembangkan adalah RPP dan media pembelajaran yaitu kartu make a match dan materi karakter siswa.

Produk pebelajaran yang dikembangkan tersebut harus ditentukan tujuan, kisi-kisi instrumen, menentukan instrument, menentukan skala instrumen dan sistem penskoran. 
Produk pengembangan draf awal kemudian akan divalidasi oleh para ahli. Produk perangkat pembelajaran ini akan divalidasi oleh dua validator pembelajaran. Penilaian produk ini digunakan untuk memperoleh masukan dari para validator tentang perbaikan produk yang dihasilkan sebelum diujicob.

4. Uji Coba Terbatas

Kegiatan pada uji coba terbatas adalah melakukan uji coba secara empiris untuk mengidentifikasi permasalahn yang muncul ketika produk perangkat pembelajaran diujicobakan.

5. Revisi Untuk Menyusun Produk Utama (lapangan)

Pada tahap ini akan dilakukan revisi berdasarkan hasil ujicoba terbatas. Revisi ini bertujuan melihat yaitu RPP dan media pembelajaran yaitu kartu make a match dalam membangun karakter siswa.

6. Uji Coba Lapangan

Uji coba lapangan digunakan untuk memperoleh kelayakan perangakat pembelajaran. pada uji coba lapangan dilakukan pre test dan post tes diakhir pembelajaran.

7. Revisi uji Coba Produk Operasional

Penyempurnaan produk hasil uji coba lapangan yaitu melakukan uji kelayakan terhadap perangkat pembelajaran, sehingga menghasilkan desain dan produk pembelajaran sehi8ngga menghasilkan desain atau produk perangkat pembelajaran yang layak diujicobakan produk operasional.

8. Uji Coba Produk Operasional

Kegiatan ini dilakukan untuk melakukan uji coba produk setelah direvisi pada uji coba lapangan. Hasil analisis produk operasional meliputi analisis data

9. Revisi Produk Akhir

Melakukan penyempurnaan terhadap produk akhir setelah dilakukan pada uji coba lapangan dan uji coba produk operasional sehingga diperoleh produk akhir.

\section{Teknik Analisis Data}

Ada dua teknik data yang digunakan untuk mengelola data yang dihimpun dari hasil review dan uji coba pengembangan produk perangkat pembelajaran yaitu dengan menggunakan analisis deskriptif kualitatif dan analisis statistik deskriptif.

\section{a. Analisis Deskriptif Kualitatif}

Analisis deskriptif kualitatif digunakan untuk mengolah data dari hasil review ahli pembelajaran, ahli materi dan ahli media pembelajaran, Analisis deskriptif kualitatif ini dilakukan dengan mengelompokkan informasi-informasi dari data kualitatif yang berupa masukan, tanggapan, kritik, saran perbaikan yang terdapat pada angket. Hasil analisis ini kemudian digunakan sebagai dasar merevisi produk pembelajaran.

\section{b. Analisis Statistik Deskriptif}

Teknik analisis statistik deskriptif digunakan untuk mengolah data yang diperoleh melalui angket dalam bentuk analisis persentase. Rumus yang digunakan untuk menghitung persentase dari masingmasing subyek adalah :

$P=\frac{\sum \mathrm{xi}}{\sum \mathrm{x}} \mathrm{x} 100 \%$

Keterangan :

(Walpole, 1992)

$P \quad=$ Presentase penilaian

$\sum \mathrm{xi}=$ Jumlah jawaban dari Validator

$\sum \mathrm{x}=$ Jumlah jawaban tertinggi

Selanjutnya untuk menghitung persentase keseluruhan subyek / komponen digunakan rumus sebagai berikut : Keterangan :

$P=\frac{\sum \mathrm{xi}}{\sum \mathrm{x}} \mathrm{x} 100 \%$

(Walpole, 1992)

$\mathrm{P}=$ Persentase keseluruhan subyek/komponen $\sum \mathrm{p}=$ Jumlah persentase keseluruhan komponen

$\sum \mathrm{n}=$ Banyak komponen

Dalam pengambilan keputusan merevisi produk, digunakan klafikasi tingkat kelayakan dan kriteria produk, yaitu:

Tabel 3.2 Konversi tingkat pencapaian dengan skala 5 yakni :

\begin{tabular}{|l|c|c|}
\hline Tingkat Pencapaian & Kualifikasi & Keterangan \\
\hline $90 \%-100 \%$ & Sangat baik & Sangat layak, tidak perlu direvisi \\
$75 \%-89 \%$ & Baik Cukup & Layak, tidak perlu direvisi \\
$65 \%-74 \%$ & baik Cukup & Cukup layak, perlu revisi \\
$55 \%-64 \%$ & Kurang Cukup & Tidak layak, perlu revisi \\
$0 \%-54 \%$ & & Sangat tidak layak, perlu revisi \\
\hline
\end{tabular}

Analisis Hasil Karakter

Hasil karakter yang diberikan berisikan lima pilihan untuk melihat karakter siswa yang dikembangkan, yaitu: Instrumen yang berupa angket digunakan 
pada awal dan akhir proses pembelajaran. Angket yang digunakan adalah angket Likert skala lima yaitu: sangat baik (5), baik (4), cukup baik (3), kurang baik (2) dan Tidak baik (1). Untuk mengetahui selisih nilai pre-test dan post-test dihitung dengan menggunakan teknik gain standar. Menurut Hake (1998: 3), rumus untuk menentukan gain standar adalah sebagai berikut:

Adapun penentuan peningkatan pembentukan karakter siswa terdapat dalam tabel 3.3

Tabel 3.3. Tingkat Gain Standar

\begin{tabular}{|c|c|}
\hline Nilai gain standar $(\mathrm{g})$ & Keterangan \\
\hline$\geq$ & Tinggi \\
\hline $0,7>\mathrm{g} \geq 0,3$ & Sedan \\
\hline$<$ & Rendah \\
\hline
\end{tabular}

\section{Hasil Pengembangan}

Produk pengembangan ini berupa RPP (Rencana Pelaksanaan Pembelajaran) oleh tim ahli yaitu Ahmad Muzanni, M.Pd dan Sintayana Muhardini, M.Pd

Berikut ini adalah paparan hasil penilaian ahli isi materi pelajaran terhadap produk pengembangan melalui metode angket dan diskusi.

\section{Penyajian Data dan Analisis Data}

Produk pengembangan yang diserahkan kepada ahli pembelajaran adalah Rencana Pelaksanaan pembelajaran (RPP). Penilaian yang dilakukan oleh ahli pembelajaran dilakukan dengan cara memberikan skor pada setiap pertanyaan yang ada dalam angket dan memberikan komentar, saran, serta mencoret bahan ajar seandainya terdapat kesalahan. Adapun rentang skor dalam angket adalah (a) 1 (Berarti sangat kurang baik), (b) 2 (Berarti kurang abaik), (c) 3 (Berarti cukup baik), (d) 4 (Berarti baik), (e) 5 (Berarti sangat baik). Berikut ini adalah penyajian data dari uji Ahli pembelajaran.

\section{a. Rencana Pelaksanan Pembelajaran (RPP)}

Hasil penilaian ahli pembelajaran terhadap RPP dapat dilihat dalam tabel berikut ini.

Tabel 4.1 Data Hasil Penilaian Ahli Pembelalajaran terhadap Rencana Pelaksanaan Pembelajaran (RPP)

\begin{tabular}{|c|c|c|c|}
\hline Jumlah item Pernyataan & Skor & Frekuensi & Persentase \\
\hline \multirow{3}{*}{27} & 5 & 20 & $74.07 \%$ \\
\cline { 2 - 4 } & 4 & 5 & $14.81 \%$ \\
\cline { 2 - 4 } & 3 & 2 & $4.4 \%$ \\
\cline { 2 - 4 } & & & $93.28 \%$ \\
\hline
\end{tabular}

Berdasarkan hasil penilaian dari seorang ahli pembelajaran terhadap RPP sebagaimana tercantum pada tabel 4.1 di atas, hasil perhitungan persentase diperoleh sebesar 93,28\% Setelah dikonversi menunjukkan bahwa perangkat pembelajaran berupa RPP dalam kualifikasi sangat baik, sehingga secara umum tidak perlu direvisi.

\section{b. Revisi Produk Pengembangan}

Berdasarkan penilaian dari ahli pembelajaran, maka tidak dilakukan revisi. Semua persentase pencapaian kelayakan, pada rencana pelaksanaan pembelajaran dalam kategori sangat baik, sehingga tidak perlu direvisi. Namun pengembang tetap melakukan perbaikan sesuai saran ahli isi mata pelajaran

\section{c. RPP (Rencana Pelaksanaan Pembelajaran)}

Berdasarkan hasil penilaian atau tanggapan yang diberikan oleh ahli pembelajaran berupa angket dan hasil observasi. Berdasarkan hasil masukan, saran dan komentar dari ahli pembelajarn maka paket pembelajaran dalam bentuk draft pengembangan diperbaiki, sehingga produk pengembangan yang dihasilkan semakin sempurna. Revisi pengembangan berupa Rencana Pelaksanaan Pembelajaran (RPP) disajikan dalam tabel di bawah ini.

Tabel 4.2 Revisi RPP Atas Masukan Ahli Pembelajaran

\begin{tabular}{|l|l|c|}
\hline No & \multicolumn{1}{|c|}{ Item yang direvisi } & \multicolumn{1}{|c|}{ Revisi } \\
\hline 1. & $\begin{array}{l}\text { Hurufnya harus di Bolt untuk judul-judul } \\
\text { Besarnya }\end{array}$ & Sudah direvisi \\
\hline 2. & Instrumen Penilaian & Sudah direvisi \\
\hline
\end{tabular}

\section{d. Uji Ahli Media Pembelajaran}

Produk pengembangan paket pembelajaran ini juga diberikan kepada seorang ahli media pembelajaran. media pembelajaran dan instrumen berupa agket diserahkan pada ahli media pembelajaran yang diminta untuk menilai produk pengembangan adalah bapak Dr. Gunawan Sakti, Beliau adalah seorang dosen Teknologi Pembelajaran di IKIP Mataram Adapun 
instrumen yang digunakan adalah angket. Berkaitan dengan desain pembelajaran, produk pengembangan media yang diminta untuk dinilai oleh ahli media pembelajaran adalah kartu make a match.

\section{Penyajian Data dan Analisis Data}

\section{a. Media Pembelajaran ( kartu make a match)}

Dibawah ini akan dipaparkan hasil penilaian ahli media pembelajaran terhadap produk pengembangan berupa Kartu make a match.

Tabel 4.3 Hasil Penilaian Ahli Media Pembelajaran Terhadap Kartu make a match.

\begin{tabular}{|c|c|c|c|}
\hline Jumlah Item pertanyaan & Skor & Frekuensi & Persentase \\
\hline \multirow[t]{3}{*}{10} & 5 & 3 & $30 \%$ \\
\hline & 4 & 6 & $48 \%$ \\
\hline & 3 & 1 & 6 \\
\hline \multicolumn{3}{|c|}{ Jumlah } & $84 \%$ \\
\hline
\end{tabular}

Masukan, saran dan komentar ahli media pembelajaran berkenaan dengan RPP yang menggunakan model make a match (kartu jawaban dan kartu jawaban) dapat memadai untuk dilakukan uji berikutnya.

1. Kualitas gambar didalam panduan perlu dipertajam

2. Kekonsistenan ukuran gambar dan huruf

3. Warna gambar harus lebih cerah lagi

Berdasarkan hasil penilaian dari seorang ahli media pembelajaran terhadap kartu make a match pada tabel 4.3 di atas, hasil perhitungan persentase diperoleh sebesar $84 \%$. Setelah dikonversikan dengan tabel konversi menunjukkan bahwa media pembelajaran dengan kartu make a match berada dalam kualifikasi baik sehingga tidak perlu direvisi.

\section{b. Uji Ahli Materi}

Produk pengembangan paket pembelajaran ini juga diberikan kepada seorang ahli materi. Materi pembelajaran dan instrumen berupa angket diserahkan kepada ahli materi untuk menilai produk pengembangan adalah Dewi rayani, M.Pd. Beliau adalah seorang Dosen di IKIP Mataram yang S2 nya psikologi. Adapun instrumen yang digunakan adalah angket. Berkaitan dengan materi pembelajaran tentang karakter produk pengembangan yang diminta untuk dinilai adalah materi pembelajaran yang berkaitan dengan karakter siswa SD pada mata pelajaran PKN.

\section{c. Penyajian Data dan Analisis Data}

Dibawah ini akan dipaparkan hasil penilaian Ahli materi tentang karakter siswa Sekolah Dasar.

Tabel 4.4 Hasil penilaian Ahli materi tentang karakter siswa Sekolah Dasar

\begin{tabular}{|c|c|c|c|c|}
\hline Indikator & Jlh Item pertanyaan & Skor & Frekuensi & Persentase \\
\hline \multirow[t]{2}{*}{ Percaya Diri } & 5 & 5 & 4 & $80.00 \%$ \\
\hline & & 4 & 1 & $16.00 \%$ \\
\hline \multicolumn{4}{|c|}{ Jumlah } & $96.00 \%$ \\
\hline \multirow[t]{2}{*}{ Tanggung Jawab } & 5 & 5 & 3 & $60.00 \%$ \\
\hline & & 4 & 2 & $32.00 \%$ \\
\hline \multicolumn{4}{|c|}{ Jumlah } & $93.00 \%$ \\
\hline \multirow[t]{2}{*}{ Kerja sama } & 5 & 5 & 3 & $60.00 \%$ \\
\hline & & 4 & 2 & $32.00 \%$ \\
\hline \multicolumn{4}{|c|}{ Jumlah } & $93.00 \%$ \\
\hline \multicolumn{5}{|c|}{ Rata-rata skor PD+TJ+KS $=\frac{96.00 \%+93.00 \%+93.00 \%}{3}=94.00 \%$} \\
\hline
\end{tabular}

Masukan, saran dan

komentar ahli materi adalah sebagai berikut:

1. Materi ahrus lebih terperinci lagi

2. Materi Hidup Rukun yangberkaitan dengan

karakter di tambahkan lagi.

Bahan hasil penilaian dari seorang ahli Materi terhadap materi pembelajaran yang berkaitan dengan karakter siswa SD sebagaimana tercantum pada tabel 4.4 di atas, hasil perhitungan persentase diperoleh sebesar 94.00\%. Setelah dikonversikan dengan tabel konversi

3. menunjukkan bahwa bahan ajar berada dalam kualifikasi sangat baik sehingga tidak perlu direvisi.

\section{d. Uji Coba Terbatas}

Berikut ini disajikan data yang diperoleh dari uji coba Terbatas sajian data dimulai dari Kartu Make a match serta materi pembelajaran.

Tabel 4.5 Data Hasil Uji Coba Terbatas produk model Kartu Make match

\begin{tabular}{|l|l|l|l|l|l|l|l|l|}
\hline \multirow{2}{*}{$\begin{array}{c}\text { Item } \\
\text { pertanyaan }\end{array}$} & \multicolumn{2}{|c|}{ Frekuensi dengan Skla 5 } & Jmlh & $\%$ & $\begin{array}{c}\text { Komentar/ } \\
\text { Saran }\end{array}$ \\
\cline { 2 - 10 } & 1 & 2 & 3 & 4 & 5 & & & \\
\hline 1 & - & - & - & 5 & 7 & 12 & 91.67 & Tidak ada \\
\hline 2 & - & - & - & 8 & 4 & 12 & 79.99 & Tidak ada \\
\hline 3 & - & - & - & 6 & 6 & 12 & 90 & Tidak ada \\
\hline 5 & - & - & - & 6 & 6 & 12 & 90 & Tidak ada \\
\hline 4 & - & - & - & 7 & 5 & 12 & 88.32 & Tidak ada \\
\hline 5 & - & - & - & 5 & 7 & 12 & 91.67 & Tidak ada \\
\hline 6 & - & - & - & 8 & 4 & 12 & 79.99 & Tidak ada \\
\hline 7 & - & - & - & 8 & 4 & 12 & 79.99 & Tidak ada \\
\hline 8 & - & - & - & 1 & 11 & 12 & 92.32 & Tidak ada \\
\hline 9 & - & - & - & 5 & 7 & 12 & 91.67 & Tidak ada \\
\hline 10 & - & - & - & 8 & 4 & 12 & 79.99 & Tidak ada \\
\hline Jumlah & & & & & 955.61 & \\
\hline Rata-rata & & & & & & & \\
\hline
\end{tabular}


Berdasarkan penilaian/ tanggapan sebagaimana tercantum dalam tabel 4.5 diketahui bahwa rata-rata persentase tingkat pencapaian bahan ajar 95,5\%, rerata tersebut bila dikonversikan dengan tabel kelayakan, maka bahan ajar berada dalam kualifikasi sangat baik dan tidak perlu direvisi.

\section{e. Revisi Produk Pengembangan}

Rangkuman masukan, saran, dan komentar 12 orang siswa dalam uji coba terbatas yang berkenaan dengan kartu make a match adalah sebagai berikut:

Tabel 4.6 Revisi Masukan, Saran Dan komentar Uji Coba terbatas Pada RPP model kartu make a match

\begin{tabular}{|l|l|l|}
\hline No & Masukan, Saran, dan Komentar & \multicolumn{1}{c|}{ Revisi } \\
\hline 1. & Sebaiknya gambar lebih cerah & $\begin{array}{l}\text { Penambahan kecerahan } \\
\text { warna pada gambar }\end{array}$ \\
\hline 2. & Gambarnya yang menarik & Tidak ada revisi \\
\hline
\end{tabular}

Rangkuman masukan, saran, dan komentar dua belas orang siswa dalam uji coba terbatas adalah sebagai berikut :

Tabel 4.7 Revisi Masukan, Saran Dan Komentar Uji Coba terbatas Pada Siswa \begin{tabular}{|l|l|l|}
\hline No & $\begin{array}{l}\text { Masukan, Saran, dan } \\
\text { Komentar }\end{array}$ & \multicolumn{1}{c|}{ Revisi } \\
\hline 1 & Sebaiknya gambar lebih cerah & $\begin{array}{l}\text { Penambahan kecerahan warna } \\
\text { pada gambar }\end{array}$ \\
\hline
\end{tabular}

\section{f. Uji Coba Lapangan}

Hasil revisi berdasarkan saran dan masukan siswa dalam uji coba kelompok kecil, dibawah ke kelas yang sebenarnya dalam uji lapangan. Uji coba lapangan dilaksanakan di SD Negeri 1 Dasan Baru. Produk pengembangan yang diuji coba kepada siswa terdiri dari RPP, materi dan model make a match untuk membangun karakter siswa. model pembelajaran yang digunakan yaitu menggunakan RPP model make a match, Tanya jawab, dan pemberian tugas. Adapun materi yang digunakan adalah materi hidup rukun pada mata pelajaran PKn karna berkaitan erat dengan karakter siswa SD.

Data-data yang diperoleh dari kegiatan uji coba lapangan disajikan secara berurutan mulai dari perangkat pembelajaran yaitu RPP, materi, dan media pembelajran.

\section{g. RPP dengan model make a match untuk membangun karakter Siswa SD}

Hasil penilaian uji coba lapangan terhadap model make a match dapat dilihat pada tabel berikut :
Hasil penilaian Uji coba lapangan terhadap RPP dengan model kartu make a match siswa dapat dilihat pada tabel berikut :

Tabel 4.8 Data Hasil Uji coba Lapangan Terhadap Siswa.

\begin{tabular}{|c|c|c|c|c|c|c|c|c|}
\hline \multirow{2}{*}{$\begin{array}{c}\text { Item } \\
\text { pertanyaan }\end{array}$} & \multicolumn{5}{|c|}{ Frekuensi dengan Skla 5} & \multirow[t]{2}{*}{ Jmlh } & \multirow[t]{2}{*}{$\%$} & \multirow{2}{*}{$\begin{array}{c}\text { Komentar/ } \\
\text { Saran }\end{array}$} \\
\hline & 1 & 2 & 3 & 4 & 5 & & & \\
\hline 1 & - & - & - & 5 & 15 & 20 & 90.00 & \\
\hline 2 & & & 2 & 6 & 12 & 20 & 90.00 & \\
\hline 3 & & & 2 & 4 & 14 & 20 & 92.00 & \\
\hline 4 & & & & 7 & 13 & 20 & 93.00 & \\
\hline 5 & & & & 2 & 18 & 20 & 98.00 & \\
\hline 6 & & & & 5 & 15 & 20 & 90.00 & \\
\hline 7 & & & 1 & 4 & 15 & 20 & 94.00 & \\
\hline 8 & & & 1 & 3 & 16 & 20 & 95.00 & \\
\hline 9 & & & & 4 & 16 & 20 & 80.00 & \\
\hline 10 & & & & 5 & 15 & 20 & 90.00 & \\
\hline \multicolumn{7}{|c|}{ Rata-rata } & 91.20 & \\
\hline
\end{tabular}

Berdasarkan hasil uji coba lapangan sebagaimana tercantum pada tabel $4.8 \mathrm{di}$ atas, skor yang diperoleh terhadap 10 komponen materi pembelajaran dengan menggunakan kartu make a match 20 siswa adalah skor 5 ( Berarti sangat baik), skor 4 (Berarti baik), skor 3 (Berarti cukup baik). Rerata persentase diperoleh sebesar 91,20\% Setelah dikonversikan dengan tabel konversi diketahui bahwa dengan menggunakan kartu model make a match berada dalam kualifikasi sangat baik.

\section{a. Hasil Karakter Siswa}

1. Rerata Pretest dan Postest pembetukan karakter pada uji coba lapangan Kelas 1 .

Tabel 4.9 Rerata Pretest dan Postest pembetukan karakter

\begin{tabular}{|l|c|c|c|}
\hline Karakter & Pretest & Postest & Gain standar \\
\cline { 1 - 1 } Percaya Diri & & & \multirow{2}{*}{2.2} \\
\cline { 1 - 1 } Tanggung Jawab & 2.66 & 0,2 \\
\cline { 1 - 1 } Kerjasama & & & \\
\hline
\end{tabular}

Berdasarkan Tabel 4.9 maka dapat disimpulkan bahwa terjadi peningkatan karakter percaya diri, tanggung jawab dan kerjasama dalam kategori "Rendah".

2. Rerata Pretest dan Postest pembetukan karakter pada uji coba lapangan Kelas 1 menggunakan model kartu make a match.

Tabel 4.10 Rerata Pretest dan Postest pembetukan karakter menggunakan kartu make a matc.

\begin{tabular}{|l|c|c|c|}
\hline Karakter & Pretest & Postest & Gain standar \\
\hline Percaya Diri & \multirow{2}{*}{2.68} & \multirow{2}{*}{4.01} & \multirow{2}{*}{0,7} \\
\cline { 1 - 1 } Tanggung Jawab & & & \\
\hline Kerjasama & & \\
\hline
\end{tabular}


Berdasarkan Tabel 4.10 maka dapat disimpulkan bahwa terjadi peningkatan karakter percaya diri, tanggung jawab dan kerjasama dalam kategori "Tinggi".

\section{KESIMPULAN}

Hasil analisis data yang dilakukan pada siswa dengan menggunakan model make a match untuk membangun karakter siswa, ada 5 siswa memperoleh nilai 90 dikategorikan sangat baik, 11 siswa memeperoleh nilai 80 dikategorikan baik dan 4 siswa yang memperoleh nilai 73 dikategorikan cukup baik.

\section{DAFTAR PUSTAKA}

Arifin dan zainal, Ahmad. (2012). Pembelajaran dari Desain Implementasi. Yogyakarta : Pedagogia.

Borg, W. R. \& Gall, M. D. (1983). Educational research: An introduction $\left(4^{\text {th }} \mathrm{ed}\right)$. New York: Longman Inc.

Djaali dan Pudji Mulyono. 2008. Pengukuran dalam Bidang Pendidikan. Jakarta : PT: Grasindo

Faturahman, P., Suryana, AA dkk. 2013. Pengembangan Pendidikan Karakter. Bandung : Refika aditama.

Lickona, T. (2012). Character Matters. Jakarta : Bumi Aksara. Lickona, T. 2008. Educating for character. New York : Bantam Book.

-------- (2011). Pedoman Pendidikan Karakter bagi Anak usia Dini. Kemendiknas, Ditjen PAUD NIDN Direktorat Pembinaan PAUD

Megawangi, Ratna.2009. Menyemai benih Karakter, Jakarta : Indonesia Heritage Foundation.

Narvaez, D., dan Lapsley, D.K. 2006. “ Teaching Moral Character. Two Strategies For Teacher Education

Sugiono. 2013. Metode Penelitian Pendekatan Kuantitatif, Kualitatif dan RND. Bandung : Alfabeta

Solihatin, Etin dan Raharjo. 2008. Cooveratif Learning Analisis Model Pembelajaran IPS. Jakarta : Bumi Aksara

Suprijono, Agus. 2011. Cooperatif Learning Teori dan Aplikasi Paikem. Yogyakarta: PT Pustaka Belajar
Wahab, Abdul Azis. (2009). Metode dan Model-model Mengajar. Bandung : Alpab 